\title{
Students' Conceptual Changes on the Air Pressure Learning Using Predict-Observe-Explain Strategy
}

\author{
Fitri Nurzakiah Fuadi ${ }^{凶}$, Wahyu Sopandi 1,2, Ghery Priscylio ${ }^{3}$, Ghullam Hamdu4, and Lidya \\ Mustikasari ${ }^{1}$
}

'Elementary Education Department, Postgraduate School, Universitas Pendidikan Indonesia, Bandung, Indonesia

${ }^{2}$ Chemistry Education Department, Faculty of Mathematics and Science Education, Universitas Pendidikan Indonesia, Bandung , Indonesia

${ }^{3}$ Science Education Department, Postgraduate School, Universitas Pendidikan Indonesia, Bandung, Indonesia

${ }^{4}$ Elementary Education Department, Universitas Pendidikan Indonesia, Tasikmalaya, Indonesia

$\bowtie$ fitrinf@upi.edu

\begin{abstract}
The concept of air-having pressure needs to be understood by students so that they can understand natural phenomena related to the air concept. The characteristic of the abstract concept of air having pressure leads students to misconceptions. The purpose of this study is to analyze changes in students' conceptions of the air-having pressure concept by using the POE strategy. The research method used was a pre-experiment with one group pretestposttest design. Pretest and posttest questions were given to students using the five-level diagnostic test instrument with a total of three questions. The ability to predict-test and the ability to observe-test were performed with four questions on each test. The participants of this study consisted of 31 fifth grade students in the even semester. The categorization of conception change is divided into five patterns: construction, revision, static, disorientation, and complementation. Based on the analysis, revision had the highest percentage followed by construction. The conclusion is that the POE strategy can help students in understanding the concept of air-having pressure so that there was a change from misconception to understanding scientific concepts.
\end{abstract}

Keywords: Misconception, conception changes, POE strategy, elementary school.

How to Cite: Fuadi, F., Sopandi, W., Priscylio, G., Hamdu, G., \& Mustikasari, L. (2020). Students' Conceptual Changes on the Air Pressure Learning Using Predict-Observe-Explain Strategy. Mimbar Sekolah Dasar, 7(1), 66-81. doi:https://doi.org/10.17509/mimbar-sd.v7i1.22457.

INTRODUCTION The development of science and technology greatly influences aspects of human life. On the one hand, technological advances provide various facilities for humans. On the other hand, this progress threatens human life with various environmental problems that it causes. One of the dangerous environmental problems is the problem of air pollution. The effect can be an increase in temperature (Bloomer, Stehr, Piety, Salawitch, \& Dickerson, 2009) to the risk of various diseases (Chen et al., 2012; Harlan \& Ruddell, 2011; Kampa \& Castanas, 2008). There are components needed by living things to breathe, produce food, communicate and even process combustion in the air. Although the surface of the earth is covered with air, many elementary school students do not know about the components and characteristics of air (Sopandi, 2009). One of the important characteristics of air to learn is that air has pressure. 
Fitri Nurzakiah Fuadi, et al. Students' Conceptual Changes on the Air Pressure Learning...

In fact, by knowing and understanding the characteristics of air, students will find various explanations about natural phenomena that occur in everyday life.

The concept of air and its characteristics are studied by students in the content of science lessons. The implementation of the science learning process requires a direct involvement of students so that students get the actual natural facts about a concept. However, it seems that the teaching of science in Indonesia still has not optimally helped students to comprehend science in everyday life. This is based on the results of the 2018 Program for International Student Assessment (PISA, 2019) which shows that Indonesia is ranked 9th from the bottom (71) in the science category. The assessment is based on students' understanding of science and scientific inquiry. Understanding of science is one of the important skills in 21st-century education and elementary students must be taught about this (Turiman, Omar, Daud, \& Osman, 2012). In addition to understanding concepts scientifically, in the process, scientific understanding helps students practice inventive thinking from analyzing to solving problems in life (Abdullah \& Osman, 2010).

Understanding the concept of air having pressure needs to be had by students so that they can apply and reason the concept correctly so that they can understand natural conditions. learning instilling an understanding of concepts becomes a very challenging thing because in the process students often experience misunderstandings of concepts. Elementary school students experience many misconceptions about basic science concepts because both texts and teachers are inadequate in dealing with their misconceptions (Eaton, Anderson, \& Smith, 2005; Pine, Messer, \& John, 2001) and personal experiences also influence student conceptions (González, 2010). The possibility of the emergence of misconceptions in students should be a concern for teachers because once a misunderstanding has formed, then it will continue and it is difficult to change it (Bayuni, Sopandi, \& Sujana, 2018; Kala, Yaman, \& Ayas, 2013; Thompson, 2006). To avoid misconceptions, in science learning especially learning about the nature of air having pressure, it is necessary to apply a learning strategy where students are actively involved physically and mentally to see and reason (Yamtinah et al., 2019). One learning strategy that can overcome misconceptions iss through the application of the Prediction, Observation, and Explanation (POE) strategy (Chang et al., 2012; Karamustafaoğlu \& Mamlok-Naaman, 2015). This strategy provides opportunities for students to produce conceptual knowledge and develop reasoning abilities that can be applied to problemsolving (Chang et al., 2012). POE emphasizes experiment-based learning where students are trained to predict, conduct experiments and explain their findings (Karamustafaoğlu \& Mamlok-Naaman, 2015). POE can be applied in the process of learning science because learning science is a direct activity that requires students to be involved in the scientific process through practice (Conn, 2014; Jasdilla, Fitria, \& Sopandi, 2019). The practice of science requires 
the use of technology to experiment, assess, and evaluate ideas and theories. Three main steps must be implemented in the learning process of POE (Chang et al., 2012; Kala et al., 2013). These stages are prediction, observation, and explanation.

There have been many studies using POE strategies to improve students' understanding of concepts at various levels of education (Akpınar, 2014; Hsu, Tsai, \& Liang, 201 1; Kibirige, Osodo, \& Tlala, 2014; Özdemir, Bağ, \& Bilen, 2011; Wu \& Tsai, 2005). Furthermore, for the concept of air, there have been several studies regarding the application of concepts about the behavior or characteristics of air (Chao, Chiu, DeJaegher, \& Pan, 2016; Wiebe \& Stinner, 2010). These studies have been carried out at the level of secondary education and above. At the early childhood level, there have also been studies on the introduction of air characteristics using POE strategies (Chiliang, 2011). However, it seems that there has been no study on the application of POE strategies to the concept of air at the elementary school level. Thus, this study aims to determine the conceptual changes students have about air pressure in elementary school. The concept of air is one of the important concepts for students in understanding the characteristics of the nature of air. Therefore, the current study was conducted to answer the research question regarding whether there was a conceptual change in students about the concept of air having pressure using the POE strategy.

\section{METHOD}

This research was conducted in the even semester in 2019. This study aimed to determine changes in students' conceptions of the concept of air having pressure by using the POE strategy. This study used an experimental method with one group pretest-posttest design. This experimental method was used as an exploratory experiment to analyze changes in the pretest and expected posttest results of the participants after receiving experimental interventions (Ary, Jacobs, \& Sorensen, 2010; Gall, Gall, \& Borg, 2010).

The study participants consisted of 31-fifth grade students in one of the elementary schools located in Bandung city. The test instrument used for data collection is an instrument designed by the researchers themselves. It was designed to determine students' conceptual changes through experiment-based learning. This instrument also tested students' ability to predict and the ability to observe. The instrument for pretest and posttest was in the form of a five-level diagnostic test. The first level was choices of answers, the second level was a level of trust in choices at the first level, the third level was an explanation of the choices of answers at the first level, the fourth level was a picture illustration to prove the explanation at the third level, and the fifth level was a level of confidence in the illustration of the picture. 
Fitri Nurzakiah Fuadi, et al. Students' Conceptual Changes on the Air Pressure Learning...

This test was chosen to produce a detailed explanation of what participants actually thought about the concepts learned either before or after the treatment was given (Anam, 2019). Meanwhile, the predicting instrument consisted of 2 questions with multiple choice answers and 2 questions with open answers. The instrument for the observation process consisted of 4 questions related to the experimental process. The test instruments were validated by experts who were lecturers in the Environmental Education Oriented Science Education Practicum course. Validity was done in connection with the adequacy, structure, language, and relevance of the instrument. The validation process by experts was not based on the score but rather direct advice on what should be improved on the test instrument.

\section{Research Procedure}

The procedures of the study began by deliberately selecting one primary school. The researchers intentionally established an experiment-based POE strategy in the teaching process about the concept of air having pressure. The learning process lasted for 90 minutes with 2 different experiments. Teaching began with a pre-test on 31 students. Next, the core teaching using the POE strategy started with 4 stages. The first stage was predicting in which the students were given a prediction sheet before experimenting. The second stage was observing during the trial period. The first experiment was about the concept of water not spilling in an upside-down bottle. The second experiment was about quail eggs that could enter the bottle even though the hole was smaller than the size of the quail. During the probationary period, the students were given observation sheets to fill out. The third stage was asking the students to explain their findings during the trial period to their friends. Finally, the post-test teaching was given to all students who participate in this teaching.

Research data were obtained from the results of the pretest, prediction test, observation test, and posttest. The results of the four tests were scored and then coded according to the students' conception level category. The students' conceptions were categorized into six levels (Anam, Widodo, Sopandi, \& Wu, 2019), namely: Scientific Conception (SC), Almost Scientific Conception (ASC), Lack of Confidence (LC) Lack of Knowledge (LK) Misconception (MSC) and Have No Conception (HNC). Next, to determine the category of conceptual change, students' answer codes in the pre-test and post-test were matched into the category of existing concept change patterns. The following table is a table for determining patterns of change in students' conceptions based on those formulated by Anam (2019).

Table 1. Patterns of change in students' conceptions

\begin{tabular}{ccccc}
\hline \multicolumn{2}{c}{ Change of Response } & & $\begin{array}{c}\text { Level of } \\
\text { Change }\end{array}$ & \\
\cline { 1 - 2 } Beginning & End & & Explanation \\
\hline HNC & LC & Construction & $\begin{array}{l}\text { There is understanding } \\
\text { construction }\end{array}$ \\
\cline { 2 - 2 } & ASC & & & Consuction
\end{tabular}




\begin{tabular}{|c|c|c|c|}
\hline \multirow[t]{4}{*}{ MC } & LK & \multirow[t]{7}{*}{ Revision } & \multirow{7}{*}{$\begin{array}{l}\text { There is revision toward initial } \\
\text { understanding }\end{array}$} \\
\hline & LC & & \\
\hline & ASC & & \\
\hline & SC & & \\
\hline \multirow[t]{3}{*}{ LK } & LC & & \\
\hline & ASC & & \\
\hline & SC & & \\
\hline \multicolumn{2}{|l|}{ No change } & Static & $\begin{array}{ll}\text { Cannot } & \text { change } \\
\text { understanding } & \end{array}$ \\
\hline \multicolumn{2}{|c|}{ backward change } & Disorientation & $\begin{array}{l}\text { There is a decrease in } \\
\text { understanding }\end{array}$ \\
\hline \multirow[t]{2}{*}{ ASC } & SC & Complementa & An improvement \\
\hline & & tion & $\begin{array}{l}\text { understanding becomes } \\
\text { scientific understanding }\end{array}$ \\
\hline
\end{tabular}

\section{RESULTS}

Research data to get a picture of changes in the conception of students on-air having pressure were obtained from several tests including the pretest, prediction test, observation test, and posttest.

\section{Profile of Students' Initial Conceptions}

Preliminary tests were conducted to determine the condition of students' initial conceptions regarding the concept of air having pressure. In this test, question no 1 is related to the concept of air pressure compared to water pressure. Then problem number 2 is related to air pressure at higher temperatures and air pressure at lower temperatures. Then, question no. 3 is about the natural phenomenon of air pollution related to the concept of air pressure. The following is the profile of students' initial conceptions obtained through the analysis of student answers in the pretest. 


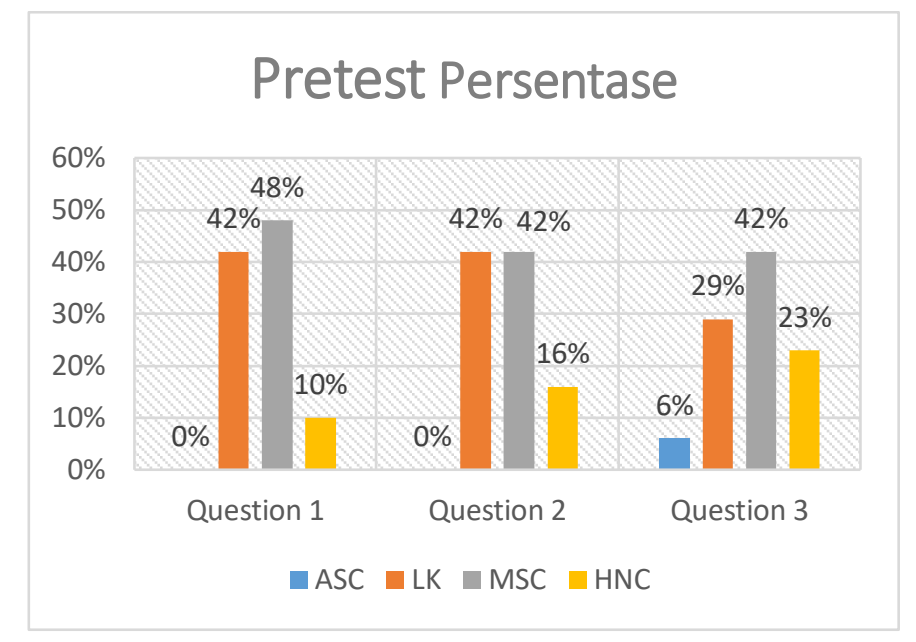

Figure 1. Profile of students' initial conception

\section{Profile of the Ability to Predict}

In the first stage of POE, students learned to predict a situation that would occur related to the application of certain concepts (Muna, 2017). Also, in this section, students were also expected to provide explanations or reasons regarding the allegations given. The results of the analysis regarding the ability to predict students are shown in Figure 2.

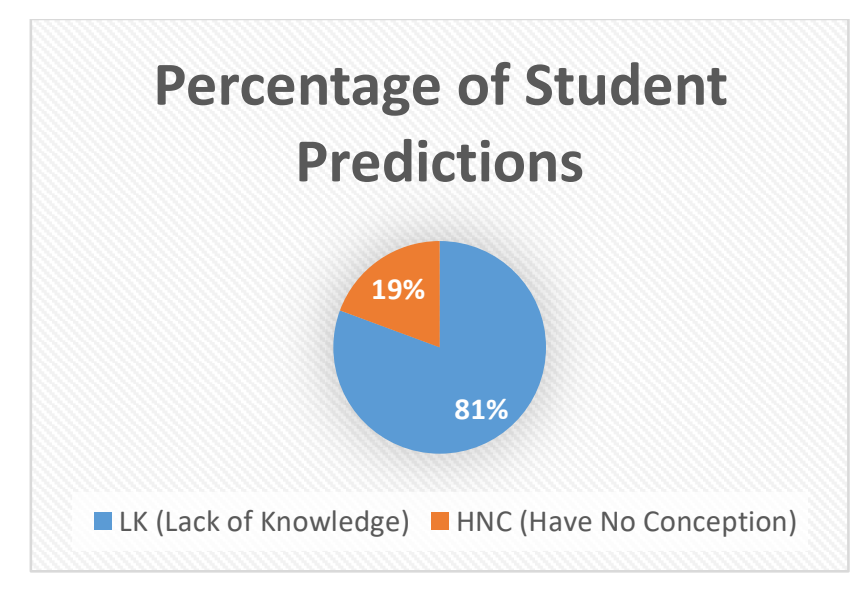

Figure 2. Students' profile of the ability to predict

\section{Profile of Students' Ability to Observe}

The second stage is the observation where students were invited to conduct experiments to test the correctness of predictions that students conveyed before. This observation phase assistsed students in developing one of the basic scientific skills (Muna, 2017; Wardani, Widodo, \& Priyani, 2009). ). The results of the analysis of the ability to observe students are shown in table 2. 
Table 2. percentage of students ability to observe

\begin{tabular}{cccc}
\hline \multirow{2}{*}{ Activities } & \multicolumn{3}{c}{ Student conception level } \\
\cline { 2 - 4 } & SC & ASC & LK \\
\hline Experiment 1 & $26 \%$ & $42 \%$ & $32 \%$ \\
\hline Experiment 2 & $23 \%$ & $58 \%$ & $19 \%$ \\
\hline
\end{tabular}

\section{Profile of Students' Final Conceptions}

Knowing the extent to which students' conceptions are related to a scientific concept is an important thing to do (Yamtinah et al., 2019). ). If there is a misconception in students, the teacher will be able to provide follow-up to develop a fully scientific concept (Gomez-Zwiep, 2008). Students' conceptions can be identified through the provision of tests, one of which is the use of five-tier diagnostic tests. After administering the treatment using the POE strategy, the students' posttest results on the concept of air having pressure were obtained as shown in Figure 3.

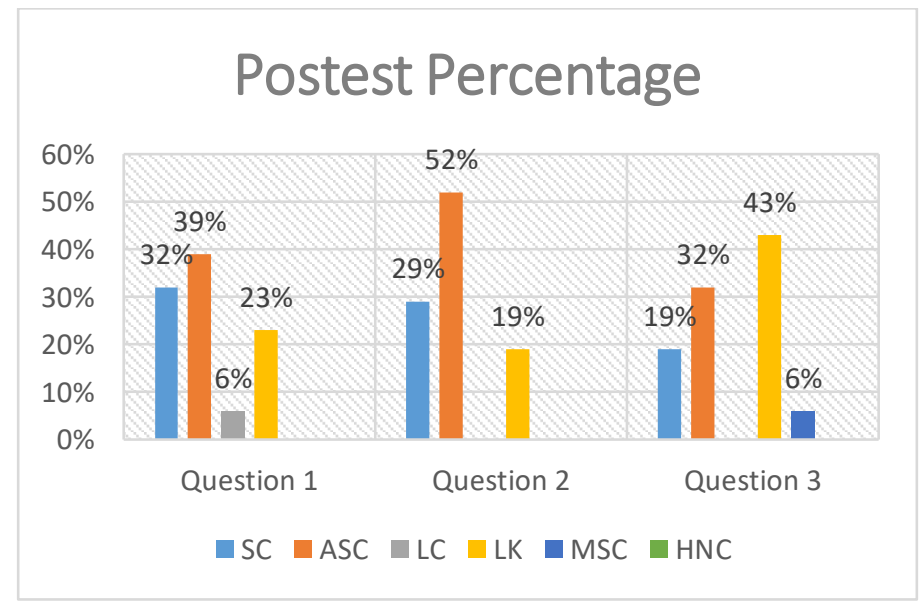

Figure 3. Students ' Final Conceptions

\section{Patterns of Change in Students' Conceptions}

Changes in conceptions that occured in each of these students certainly varied according to the initial concept they had and the ability of each student understanding. The category of level changes in students' conceptions and the number of percentages can be seen in table 3. 
Fitri Nurzakiah Fuadi, et al. Students' Conceptual Changes on the Air Pressure Learning...

Table 3. categories of change in students' conceptions

\begin{tabular}{lccc}
\hline \multirow{2}{*}{ Questions } & \multicolumn{3}{c}{ Level of Conception Change } \\
\cline { 2 - 4 } & Construction & Revision & Static \\
\hline Question 1 & $10 \%$ & $80 \%$ & $10 \%$ \\
\hline Question 2 & $16 \%$ & $74 \%$ & $10 \%$ \\
\hline Question 3 & $23 \%$ & $54 \%$ & $23 \%$ \\
\hline
\end{tabular}

\section{DISCUSSION}

\section{Profile of Students' Initial Conceptions}

When going to discuss science topics for the first time the teacher cannot assume that students know nothing about these science topics because students have developed their assumptions about science topics even before learning begins (Taber, 2016). This initial knowledge or initial conception is obtained through interactions in daily life that can play an important role in learning (Brown \& Clement, 1989). Students 'perceptions about scientific topics vary (Taber, 2016), some are in accordance with scientific concepts, some are not completely true, but what often happens is that students' knowledge of natural phenomena is different from true scientific views (Bayraktar, 2009). In the pretest questions, there were 3 questions with different indicators and each question was based on a five-tier diagnostic test. By using a diagnostic test at the beginning, the researcher can obtain clear information about knowledge and misunderstanding about the topic to be discussed (Lazarowitz \& Lieb, 2006; Prodjosantoso, Hertina, \& Irwanto, 2019).

Based on Figure 1, there is a tendency that students' conceptions of air having pressure are between levels of ASC, LK, MSC, and HNC. There are no students at the ASC level In questions no. 1 and 2, while in question no. 3, about $6 \%$ of students are at the ASC level. LK level appears in all three questions with the same percentage in questions no. 1 and 2. Then, the MSC level appears most dominant in questions no. 1 and 3. These data indicate that the initial conceptions that many students have are in the category of misconceptions. Their conceptions are categorized as misconceptions because students provide answers that do not fit scientific concepts, and at questions of confidence level, students respond confidently to their answers. In the answers, students believe more in the role of objects in the experiment, not in the role of pressure from the air. Many sources contribute to misunderstandings, ranging from personal experiences, family, friends, analogies, media, teachers, and textbooks (Bayraktar, 2009; Moodley \& Gaigher, 2019). Student misunderstandings will affect the way students learn new scientific knowledge that plays an important role in further learning and becomes a barrier in gaining true knowledge (Özmen, 2004). In addition, based on the data in Figure 1 , it is also found that there are still students who do not have a concept of air pressure. 
By knowing the state of students 'initial conceptions, teachers can consider more meaningful learning arrangements to build scientific concepts on students' thinking (Kala et al., 2013; Malleus, Kikas, \& Marken, 2017).

\section{Profile of the Ability to Predict}

Figure 2 shows that the ability of students to predict the concept of air having pressure is at the LK and HNC levels only. LK level dominates most students. This means that students' conception of air having pressure is still lacking so students are less able to predict what will happen about the experiments that will be conducted. In addition, there are some students who are at the $\mathrm{NHC}$ level, meaning the answers to predictions made are not in accordance with the concept of air. In question no. 1, the question asked is about the condition of the water in the bottle if the position of the bottle is reversed. For this answer, most students predict that the water in the bottle will spill, then in the explanation section, no student has mentioned the presence of air pressure.

The ability to predict arises as a result of the initial conception possessed by students. Justification at the prediction stage provides opportunities for students to classify and justify their own pre-conceptions (Hsu et al., 2011). This knowledge is important to know because it can give teachers information about students' difficulties in achieving new concepts and choosing strategies that effectively help students to overcome difficulties (Yang, Noh, Scharmann, \& Kang, 2014).

\section{Profile of the Ability to Observe}

After doing the observations on the experiments, students' understanding of the concept of air pressure has improved from the concept they have before. Based on table 2 it appears that the ability of students to observe the concept of air having pressure is at 3 levels, namely SC, ASC, and LK. In experiments 1 and 2, the highest level category of students is at the ASC level. By conducting experiments, students can understand the concept of air pressure by directly seeing how the work of the air pressure. By conducting experiments, it is hoped that there will be a process of reconstructing new concepts from the initial concepts students have. Next, students make repeated observations, make measurements, analyze, and interpret data which then ends by drawing conclusions that are in accordance with scientific concepts. Through this activity, students carry out experimental learning activities through concrete activities and can find their own answers to the problems they face so that learning activities become meaningful to students (Ariyati, 2018; Wardani et al., 2009). When observing activities are carried out by students, teachers should not be careless in presenting situations. In POE strategies, teachers need to present situations where students will feel stimulated and challenged and can discuss with peers about the ideas they have obtained (Adebayo \& Olufunke, 2015). 
Fitri Nurzakiah Fuadi, et al. Students' Conceptual Changes on the Air Pressure Learning...

\section{Profile of Students' Final Conceptions}

Based on Figure 3, it can be observed that after learning is given using the POE strategy, the students' conception level has improved with the emergence of the SC level. This SC level indicates that students can achieve scientific conceptions in air pressure lessons. In questions no. 1 and no. 2, most of the students' answers are at the ASC level which shows that most students have almost understood the scientific concept of air pressure, although not as a whole. Then, for question number 3, most of the students' answers are at the LK level. This means that there is still little information that can be understood by students regarding the concept of air having a pressure associated with natural phenomena in everyday life. On the question of understanding related to this natural phenomenon, there are still students who experience misconceptions even though the percentage is smaller than the pretest. One of the factors causing misconceptions is the lack of teachers 'understanding of the basic concepts of science that they teach, resulting in misinformation on students' understanding (Atwood, Christopher, Combs, \& Roland, 2010; Yates \& Marek, 2013). Another factor can be caused by the textbooks used by them (Arntzen, Lokke, Lokke, \& Eilertsen, 2010; Yamtinah et al., 2019). In addition, misconceptions can occur because students tend to memorize concepts rather than understand concepts so that when connected with the real world they will have difficulties (Banda, Mumba, Chabalengula, \& Mbewe, 2011). Students must continue to be guided and facilitated by teachers to learn actively and find concepts so that misconceptions can be corrected into scientific concepts (Gomez-Zwiep, 2008; Radzi, Abdullah, \& Muruthi, 2017). Through POE, students' misconceptions that are detected at the initial test stage and predictions can gradually be transformed into scientific concepts. Furthermore, POE presents learning by direct observation. thus, the concept will be formed completely and last longer. After gaining scientific experience, students learn to explain the connection between their experiments and their scientific concepts. Thus, students not only gain knowledge but also reason knowledge.

\section{Changing Patterns of Students' Conceptions}

Before learning begins, students actually already have their own initial understanding/ conception about the various problems of natural events (Yamtinah et al., 2019). The conception is obtained by students from the results of their interaction with nature or with people around or from reading sources they have read. In responding to new information obtained, students can maintain their initial conception substantially (no change) or replace it due to inconsistencies (Hewson, 2011).

Table 3 shows that the majority of students make improvements regarding their understanding of the concept of air having pressure. This concept is, in fact, a concept that is close to the daily lives of students. Therefore, the concept of air is important to teach to elementary students 
(Chiliang, 2011). The concept of air is taught in elementary schools through lessons in the form of objects and their characteristics, but this concept is rarely discussed in depth by the teacher. POE strategies can be used to correct misunderstandings of concepts to improve students' understanding of concepts in the learning process (Hsu et al., 2011; Kearney, 2004; Kibirige et al., 2014). In its implementation, the teacher's role is to explore students' understanding by asking them to carry out three main tasks, namely predicting, observing, and explaining. The advantage of this POE strategy is that students are invited to make predictions about a concept to be learned and students are actively involved in the search for scientific truth through experimental activities. This research shows that direct experiments can help students understand the concept of air pressure in an easy way.

\section{CONCLUSION}

Understanding of scientific concepts is important for students to have. This is because correct understanding can help students create solutions to problems in their lives either through an idea or work. Based on the results of the intervention using the POE strategy, most students could understand the scientific concept of air pressure. This strategy helped to minimize the occurrence of misunderstandings in students' minds. In teaching practice, students were interested in experiment-based teaching. They could see how natural phenomena that occur out there can be witnessed in the classroom. With the results obtained, it can be concluded that this POE strategy could be applied to help students understand other science concepts. This research is expected to contribute to efforts to understand science concepts in elementary school students through the implementation of the POE strategy so that it can be the basis for the future implementation of the POE strategy.

\section{REFERENCES}

Abdullah, M., \& Osman, K. (2010). 21 st Century Inventive Thinking Skills Among Primary Students in Malaysia and Brunei. Procedia - Social and Behavioral Sciences, 9, 1646-1651. https://doi.org/10.1016/j.sbspro.2010.12.380

Adebayo, F., \& Olufunke, B. T. (2015). Generative and Predict-Observe-Explain Instructional Strategies: Towards Enhancing Basic Science Practical Skills of Lower Primary School Pupils. International Journal of Elementary Education, 4(4), 86-92. https://doi.org/10.11648/j.ijeedu.20150404.12

Akpınar, E. (2014). The use of interactive computer animations based on POE as a presentation tool in primary science teaching. Journal of Science Education and Technology, 23(4), 527-537. https://doi.org/10.1007/s10956-013-9482-4

Anam, R. S. (2019). Analisis Representasi dan Perubahan Konsepsi Guru Serta Siswa Sekolah dasar pada Materi Perpindahan Kalor. Universitas Pendidikan Indonesia. 
Fitri Nurzakiah Fuadi, et al. Students' Conceptual Changes on the Air Pressure Learning...

Anam, R. S., Widodo, A., Sopandi, W., \& WU, H. K. (2019). Developing a Five-Tier Diagnostic Test to Identify Students' Misconceptions in Science: An Example of The Heat Transfer Concepts. Elementary Education Online, 18(3), 1014-1029. https://doi.org/10.17051/ilkonline.2019.609690

Ariyati, E. (2018). Pembelajaran Berbasis Praktikum Untuk Meningkatkan Kemampuan Berpikir Kritis Mahasiswa. Jurnal Pendidikan Matematika Dan IPA, I(2), 1-12. https://doi.org/10.26418/jpmipa.v1i2.194

Arntzen, E., Lokke, J., Lokke, G., \& Eilertsen, D. E. (2010). On misconceptions about behavior analysis among university students and teachers. Psychological Record, 60(2), 325-336. https://doi.org/10.1007/BF03395710

Ary, D., Jacobs, L. C., \& Sorensen, C. (2010). Introduction to Research in Education. (Chris Shortt, Ed.) (Eighth). Canada: Nelson Education, Ltd.

Atwood, R. K., Christopher, J. E., Combs, R. K., \& Roland, E. E. (2010). In-Service Elementary Teachers' Understanding of Magnetism Concepts Before and After Non-Traditional Instruction. Sci. Educator, 19(1), 64-76. Retrieved from http://www.etsu.edu/cas/math/mathexcellence/documents/2010_Spring_Vol_19-

_No_1_Science_Educator.pdf\#page=66\%5Cnpapers3://publication/uvid/4DCC9CE076E3-4415-9156-524CBD810E3D

Banda, A., Mumba, F., Chabalengula, V. M., \& Mbewe, S. (2011). Teachers' understanding of the particulate nature of matter: The case of Zambian pre-service science teachers. AsiaPacific Forum on Science Learning and Teaching, 12 (2), 1-17.

Bayraktar, S. (2009). Misconceptions of Turkish pre-service teachers about force and motion. International Journal of Science and Mathematics Education, 7(2), 273-291. https://doi.org/10.1007/s10763-007-9120-9

Bayuni, T. C., Sopandi, W., \& Sujana, A. (2018). Identification misconception of primary school teacher education students in changes of matters using a five-tier diagnostic test. Journal of Physics: Conference Series, 1013(1). https://doi.org/10.1088/1742-6596/1013/1/012086

Bloomer, B. J., Stehr, J. W., Piety, C. A., Salawitch, R. J., \& Dickerson, R. R. (2009). Observed relationships of ozone air pollution with temperature and emissions. Geophysical Research Letters, 36(9), 1-5. https://doi.org/10.1029/2009GL037308

Brown, D. E., \& Clement, J. (1989). Overcoming misconceptions via analogical reasoning: abstract transfer versus explanatory model construction. Instructional Science, 18(4), 237261. https://doi.org/10.1007/BF00118013 
Chang, J., Chen, C., Tsai, C., Chen, Y., Chou, M., \& Chang, L. (2012). Probing and Fostering Students' Reasoning Abilities with a Cyclic Predict-Observe-Explain Strategy. Chemistry Education and Sustainability in the Global Age, 49-57. https://doi.org/10.1007/978-94-0074860-6

Chao, J., Chiu, J. L., De Jaegher, C. J., \& Pan, E. A. (2016). Sensor-Augmented Virtual Labs: Using Physical Interactions with Science Simulations to Promote Understanding of Gas Behavior. Journal of Science Education and Technology, 25(1), 16-33. https://doi.org/10.1007/s10956-015-9574-4

Chen, R., Kan, H., Chen, B., Huang, W., Bai, Z., Song, G., \& Pan, G. (2012). Association of Particulate Air Pollution with Daily Mortality: The China Air Pollution and Health Effects Study. American Journal of Epidemiology, 175(11), 1173-1181. https://doi.org/10.1093/aje/kwr425

ChiLiang, J. (2011). Using POE to Promote Young Children's Understanding of the Properties of Air. Asia-Pacific Journal of Research in Early Childhood Education, 5(1), 45-68.

Conn, S. A. eld and C. A. (2014). Media Rich Instruction. In R. Papa (Ed.), Media Rich Instruction. New York: Springer. https://doi.org/10.1007/978-3-319-00152-4

Eaton, J. F., Anderson, C. W., \& Smith, E. L. (2005). Students' Misconceptions Interfere with Science Learning: Case Studies of Fifth-Grade Students. The Elementary School Journal, 84(4), 365-379. https://doi.org/10.1086/461370

Gall, M. D., Gall, J. P., \& Borg, W. R. (2010). Gall, M. D. Gall, Joyce P, and Borg, Walter R. (2010). Applying Educational Research. USA: Pearson Education. (Sixth Edit). United of State: Pearson Education.

Gomez-Zwiep, S. (2008). Elementary teachers' understanding of students' science misconceptions: Implications for practice and teacher education. Journal of Science Teacher Education, 19(5), 437-454. https://doi.org/10.1007/s10972-008-9102-y

González, F. M. (2010). Diagnosis of Spanish Primary School Students' Common Alternative Science Conceptions. School Science and Mathematics, 97(2), 68-74. https://doi.org/10.1111/j.1949-8594.1997.tb17345.x

Harlan, S. L., \& Ruddell, D. M. (2011). Climate change and health in cities: Impacts of heat and air pollution and potential co-benefits from mitigation and adaptation. Current Opinion in Environmental Sustainability, 3(3), 126-134. https://doi.org/10.1016/j.cosust.2011.01.001

Hewson, P. W. (2011). European Journal of Science A Conceptual Change Approach to 
Fitri Nurzakiah Fuadi, et al. Students' Conceptual Changes on the Air Pressure Learning...

Learning Science A Conceptual Change Approach to Learning Science. European Journal of Science Education, (September 2013), 37-41. https://doi.org/https://doi.org/10.1080/0140528810304004

Hsu, C. Y., Tsai, C. C., \& Liang, J. C. (2011). Facilitating Preschoolers' Scientific Knowledge Construction via Computer Games Regarding Light and Shadow: The Effect of the Prediction-Observation-Explanation (POE) Strategy. Journal of Science Education and Technology, 20(5), 482-493. https://doi.org/10.1007/s10956-011-9298-z

Jasdilla, L., Fitria, Y., \& Sopandi, W. (2019). Predict Observe Explain (POE) Strategy Toward Mental Model of Primary Students. Journal of Physics: Conference Series, 1157(2). https://doi.org/10.1088/1742-6596/1157/2/022043

Kala, N., Yaman, F., \& Ayas, A. (2013). The Effectiveness of Predict-Observe-Explain Technique in Probing Students' Understanding About Acid-Base Chemistry: A Case for The Concepts Of $\mathrm{Ph}, \mathrm{PoH}$, and Strength. International Journal of Science and Mathematics Education, 11 (3), 555-574. https://doi.org/10.1007/s10763-012-9354-z

Kampa, M., \& Castanas, E. (2008). Human Health Effects of Air Pollution. Environmental Pollution, 151 (2), 362-367. https://doi.org/10.1016/j.envpol.2007.06.012

Karamustafaoğlu, S., \& Mamlok-Naaman, R. (2015). Understanding electrochemistry concepts using the predict-observe-explain strategy. Eurasia Journal of Mathematics, Science and Technology Education, 11 (5), 923-936. https://doi.org/10.12973/eurasia.2015.1364a

Kearney, M. (2004). Multimedia Predict-Observe-Explain Social Constructivist Learning Environment. Research in Science Education, 427-453.

Kibirige, I., Osodo, J., \& Tlala, K. M. (2014). The Effect of Predict-Observe-Explain Strategy on Learners' Misconceptions about Dissolved Salts. Mediterranean Journal of Social Sciences, 5(4), 300-310. https://doi.org/10.5901/mjss.2014.v5n4p300

Lazarowitz, R., \& Lieb, C. (2006). Formative Assessment Pre-Test To Identify College. International Journal of Science and Mathematical Education, (April 2005), 741-762. https://doi.org/10.1007/s10763-005-9024-5

Malleus, E., Kikas, E., \& Marken, T. (2017). Kindergarten and Primary School Children's Everyday, Synthetic, and Scientific Concepts of Clouds and Rainfall. Research in Science Education, 47(3), 539-558. https://doi.org/10.1007/s11165-016-9516-z

Moodley, K., \& Gaigher, E. (2019). Teaching Electric Circuits: Teachers' Perceptions and Learners' Misconceptions. Research in Science Education, 49(1), 73-89. 
https://doi.org/10.1007/s1 $1165-017-9615-5$

Muna, I. A. (2017). Model Pembelajaran POE (Predict-Observe-Explain) Dalam Meningkatkan Pemahaman Konsep dan Keterampilan Proses IPA. Jurnal Studi Agama, 5(1).

Özdemir, H., Bağ, H., \& Bilen, K. (2011). Effect of Laboratory Activities Designed Based on Prediction-Observation -Explanation (Poe) Strategy on Pre-Service Science Teachers' Understanding of Acid- Base Subject. Western Anatolia Journal of Educational Sciences, (Selected papers presented at WCNTSE), 169-174.

Özmen, H. (2004). Some Student Misconceptions in Chemistry: A Literature Review of Chemical Bonding. Journal of Science Education and Technology, 13(2), 147-159. https://doi.org/10.1023/b:jost.0000031255.92943.6d

Pine, K., Messer, D., \& John, K. (2001). Children's Misconceptions in Primary Science: a survey of teachers' views. Research in Science \& Technological Education, 19(1), 79-96. https://doi.org/10.1080/0263514012004624 0

PISA. (2019). PISA 2018 Results Combined Executive Summaries. Organisation for Economic Cooperation and Development (Vol. I, II, and). https://doi.org/10.1017/СВO9781107415324.004

Prodjosantoso, A. K., Hertina, A. M., \& Irwanto. (2019). The misconception diagnosis on ionic and covalent bonds concepts with three tier diagnostic test. International Journal of Instruction, 12(1), 1477-1488. https://doi.org/10.29333/iji.2019.12194a

Radzi, R. M., Abdullah, M. N. S., \& Muruthi, K. (2017). Inquiry-Discovery Teaching Approach as a Means to Remediate Primary Students' Misconceptions About the Phases of the Moon. In Overcoming Students' Misconceptions in Science: Strategies and Perspectives from Malaysia (pp. 71-87). Singapore: Springer Nature Singapore. https://doi.org/10.1007/978981-10-3437-4_5

Sopandi, W. (2009). Mengenal Sifat-sifat Tanah, Air, Api, dan Udara Melalui Percobaan Sederhana. Bandung: Afrindo Raya. Editor: Tim Redaksi. Bandung.

Taber, K. S. (2016). The Nature of Student Conceptions in Science. In Science Education (pp. 119-131). https://doi.org/10.1007/978-94-6300-749-8_9

Thompson, F. S. L. (2006). An exploration of common student misconceptions in science. International Education Journal, 7(4), 553-559. https://doi.org/10.1016/j.sbspro.2014.07.465

Treagust, D. (1986). Evaluating Students' Misconceptions by Means of Diagnostic Multiple 
Fitri Nurzakiah Fuadi, et al. Students' Conceptual Changes on the Air Pressure Learning...

Choice Item. Research in Science Education, 16(13), 199-207.

Turiman, P., Omar, J., Daud, A. M., \& Osman, K. (2012). Fostering the 21 st Century Skills through Scientific Literacy and Science Process Skills. Procedia - Social and Behavioral Sciences, 59, 110-116. https://doi.org/10.1016/j.sbspro.2012.09.253

Wardani, S., Widodo, A. T., \& Priyani, N. E. (2009). Peningkatan Hasil Belajar Siswa Melalui Pendekatan Keterampilan Proses Sains Berorientasi Problem-Based Instruction. Jurnal Inovasi Pendidikan Kimia, 3(1), 391-399.

Wiebe, R., \& Stinner, A. (2010). Using Story to Help Student Understanding of Gas Behavior. Interchange, 41 (4), 347-361. https://doi.org/10.1007/s10780-010-9135-y

Wu, Y. T., \& Tsai, C. C. (2005). Effects of constructivist-oriented instruction on elementary school students' cognitive structures. Journal of Biological Education, 39(3), 113-119. https://doi.org/10.1080/00219266.2005.9655977

Yamtinah, S., Indriyanti, N. Y., Saputro, S., Mulyani, S., Ulfa, M., Mahardiani, L., ... Shidiq, A. S. (2019). The identification and analysis of students' misconception in chemical equilibrium using computerized two-tier multiple-choice instrument. Journal of Physics: Conference Series, 1157(4). https://doi.org/10.1088/1742-6596/1157/4/042015

Yang, C., Noh, T., Scharmann, L. C., \& Kang, S. (2014). A Study on the Elementary School Teachers' Awareness of Students' Alternative Conceptions about Change of States and Dissolution. Asia-Pacific Education Researcher, 23(3), 683-698. https://doi.org/10.1007/s40299-013-0140-7

Yates, T. B., \& Marek, E. A. (2013). Is Oklahoma really OK? A regional study of the prevalence of biological evolution-related misconceptions held by introductory biology teachers. Evolution: Education and Outreach, 6(1), 1-20. https://doi.org/10.1186/1936-6434-6-6 